\title{
SYNTHESIS, CHARACTERIZATION AND BIOLOGICAL ACTIVITY OF POLYMER NICKEL (II) COMPLEX
}

\author{
Mahmoud M. Elaasser ${ }^{\mathrm{a}}$, Ahmed G. Ibrahim ${ }^{\mathrm{b}}$, Alaa Fahmy ${ }^{\mathrm{b}}$, Ibrahim Osman ${ }^{\mathrm{b}}$, Hussein H. El-Shiekh ${ }^{\mathrm{c}}$, Farag \\ Abd El-Haib and Ahmed M. Salah. ${ }^{\text {a }}$ \\ ${ }^{a}$ Regional Center for Mycology and Biotechnology, Al-Azhar University, Nasr City, Cairo, Egypt \\ E-mail: mmelaasser@hotmail.com \\ ${ }^{\mathrm{b}}$ Department of Chemistry, Faculty of science, Al-Azhar University, Nasr City, Cairo, Egypt \\ E-mail: ahmed_polytech@yahoo.com, ahmedchemister@yahoo.com \\ ${ }^{\mathrm{c}}$ Department of Botany and Microbiology, Faculty of Science, Al-Azhar University Nasr City, Cairo, Egypt \\ E-mail: dr_ahmedsalah_lab@yahoo.com
}

\begin{abstract}
4-vinyl pyridine nickel complex containing polymerizable vinyl group, prepared by condensing (4:1 molar ratio) of 4-vinyl pyridine with Nickel chloride, then polymerized with methyl methacrylate at $70^{\circ} \mathrm{C}$ using AIBN as initiator. Metal complex and polymer metal complex have been characterized by elemental analyses, molar conductance, IR, ${ }^{1} \mathrm{H}-\mathrm{NMR}$, Mass spectra and thermal analyses (DTA and TGA). Conductivity measurement reveals the nonelectrolytic nature of the complex. This confirms that, the anion is coordinated to the metal ion. The IR reveal the metal ion is coordinated via the nitrogen atom of 4-VP. Nickel complex and polymer nickel complex have been tested invitro against number of tumor and number of microorganisms in order to assess their anti tumor and antimicrobial properties. The antimicrobial activity was observed by compounds VP-Ni and MMA-VP-Ni under the screening conditions. The activity against HCT-116 cells was detected for compound VP-Ni (with $\mathrm{IC}_{50}$ value $9.8 \pm 0.6 \mu \mathrm{g} / \mathrm{ml}$ ), compared with reference standard $(24.6 \pm 0.3 \mu \mathrm{g} / \mathrm{ml})$ followed by MMA-VP-Ni (48.3 \pm 1.5$)$. In conclusion, this study highlighted the synthesis of polymer nickel complex, and proved the promising biological activity of the synthesized compounds.
\end{abstract}

Keywords: Vinyl pyridine, nickel complex, polymer nickel complex, anti tumor and antimicrobial activity.

\section{INTRODUCTION}

Late transition metal complexes [1]', due to their less oxophilic nature relative to early transition metal complexes[2] and lanthanide metal complexes [3], are generally considered to be more tolerant toward polar functional monomer, which makes them likely targets to the development of catalysts for the polymerization of polar monomers including methyl methacrylate (MMA). Nickel (II) complexes bearing N, O-chelate ligand activation for MMA polymerization yielded poly (methyl methacrylate) (PMMA) with rich syndiotacticity microstructure [4-10]. The chelating polymers find applications in bioinorganic industry [11], wastewater treatment [12,13], pollution control [14], hydrometallurgy [15], preconcentration [16], anionic polyelectrolyte hydrogels [17], cation-exchange resins [18], showed potential applications in material science as conductive [19], luminescent [20], magnetic, porous, chiral or non-linear optical materials [21], catalytic [22-25],organic synthesis [26], polymer drug graft, recovery of trace metal ions [13] and antimicrobial activities [27,28].

\section{EXPERIMENTAL}

\subsection{Materials}

The monomers 4-vinyl pyridine (4-VP, Aldrich, 95\%) and Methyl methacrylate (MMA, 99\%), were purchased from SigmaAldrich Company. 2,2' -Azobis (isobutyronitrile) (AIBN; initiator) was purchased from Merck. $\mathrm{NiCl}_{2} .6 \mathrm{H}_{2} \mathrm{O}$ (II) ( $\left.\mathrm{Merck}, 95 \%\right)$ were used as received. All solvents and the reagents were of the best grade available and used without further purification.

\subsection{Synthesis of VP-Ni complex.}

A filtered ethanolic $(100 \mathrm{ml})$ of $\mathrm{NiCl}_{2} .6 \mathrm{H}_{2} \mathrm{O}(0.5 \mathrm{gm}, 0.0021 \mathrm{~mol})$ was added to an ethanolic (100 ml) of the 4-VP, (0.884 gm, $0.0084 \mathrm{~mol}$ ), [1M:4L] Complex (VP-Ni). The mixture was refluxed with stirring for one hour at $60{ }^{\circ} \mathrm{C}$, and then the mixture is cooled to room temperature. The green complex formed was filtered off, washed several times with ethanol and dried under vacuum over $\mathrm{P}_{4} \mathrm{O}_{10}$. The possible mechanism of the produced complex was represented in Fig 1 . The reaction yield and physicochemical characteristics of the prepared VP-Ni complex was determined (Table1). 
Table 1: Physicochemical data of the prepared VP-Ni complex

\begin{tabular}{|c|c|c|c|c|c|c|c|c|c|c|c|c|}
\hline \multirow{3}{*}{$\begin{array}{c}\text { Metal } \\
\text { complex }\end{array}$} & \multirow{3}{*}{$\begin{array}{c}\text { Yield } \\
\%\end{array}$} & \multirow{3}{*}{$\begin{array}{l}\text { Molecular } \\
\text { Formula }\end{array}$} & \multirow{3}{*}{ M.Wt } & \multirow{3}{*}{$\begin{array}{l}\text { m.p } \\
\left({ }^{\circ} \mathrm{C}\right)\end{array}$} & \multirow{3}{*}{ Color } & \multicolumn{6}{|c|}{ Elemental analysis } & \multirow{3}{*}{$\begin{array}{c}\text { Molar } \\
\text { conductivity }\end{array}$} \\
\hline & & & & & & \multicolumn{2}{|c|}{$\% \mathrm{C}$} & \multicolumn{2}{|c|}{$\% \mathrm{H}$} & \multicolumn{2}{|c|}{$\% N$} & \\
\hline & & & & & & Calcd & found & Calcd & found & Calcd & found & \\
\hline $4-\mathrm{VP}-\mathrm{Ni}$ & 55 & $\mathrm{C}_{28} \mathrm{H}_{40} \mathrm{Cl}_{2} \mathrm{~N}_{4} \mathrm{NiO}_{6}$ & 658 & $>300$ & Green & 51.09 & 51.8 & 6.13 & 6.07 & 8.51 & 8.49 & 11.6 \\
\hline
\end{tabular}

\subsection{Synthesis of polymer Ni complex.}

Metal complex $(1.0 \mathrm{~g})$ was added to Methyl methacrylate $(4.0 \mathrm{~g})$ in dimethylsulfoxide (DMSO; $50 \mathrm{~mL})$. The mixture was refluxed with stirring for $30 \mathrm{~min}$. Azobisisobutyronitrile (AIBN; $100 \mathrm{mg}, 0.6 \mathrm{mmol}$ ) initiator was added to the mixture. The system was placed in a water bath at $70 \pm 1^{\circ} \mathrm{C}$ for about $3 \mathrm{~h}$ and stirred at an appropriate speed. At the end of the reaction, the system was cooled to room temperature, and the products was filtered, washed with methanol and DMSO. then dried at $60{ }^{\circ} \mathrm{C}$ for $2 \mathrm{~h}$. The product will be referred here as MMA-VP-Ni. The possible mechanism of the produced polymer complex is represented in Fig 2. The yield of the polymer complex is defined in Eq. (1):

Yield $=\frac{M_{\text {polymer complex }}}{M_{\text {monomer }}+M_{V P-\text { complex }}} \times 100$

Where $M$ is the weight of the reagent $(\mathrm{g})$, and $\mathrm{M}_{\text {polymer complex }}$ is the total weight obtained after washing. The yield was determined gravimetrically.

\subsection{Solubility studies}

Solubility of the VP-Ni complex and MMA-VP-Ni were tested in a different polar and non-polar solvents. About 5-10 mg of the sample was added to about $2 \mathrm{ml}$ of the respective solvent in a test tube and kept overnight with the tube tightly closed. The solubility of the compounds were noted after 24 hours.

\subsection{Physical and spectroscopic measurements}

$\mathrm{C}, \mathrm{H}$ and $\mathrm{N}$ analyses were determined at the Analytical Unit of Cairo University, Egypt. The IR spectra were measured in $\mathrm{KBr}$ using a Perkin-Elmer 683 spectrophotometer $\left(4000-200 \mathrm{~cm}^{-1}\right)$. The conductance of $\left(10^{-3} \mathrm{M}\right)$ solutions of the complex in DMSO was measured at $25{ }^{\circ} \mathrm{C}$ with a Bibby conductimeter type $\mathrm{MCl}$. ${ }^{1} \mathrm{H}$ NMR spectra were obtained with Perkin-Elmer R32-90-MHz spectrophotometer using TMS as internal standard. Mass spectra of metal complex was recorded using JEULJMS-AX-500 mass spectrometer provided with data system. The thermal analyses (DTA and TGA) were carried out in air on a Shimadzu DT-30 thermal analyzer from 27 to $1000{ }^{\circ} \mathrm{C}$ at a heating rate of $10^{\circ} \mathrm{C}$ per minute. DPPH was used as a standard material. The T.L.C of the metal complex confirmed their purity.

\subsection{Biological studies}

\subsubsection{Assessment of antibacterial and antifungal activity}

Antimicrobial activity of tested metal complex and polymer metal complex were assessed against four bacterial strains (Escherichia coli, Pseudomonas aeruginosa, Bacillus subtilis and Staphylococcus pneumoniae) and two fungal strains (Aspergillus fumigatus and Candida albicans). All microorganisms were kindly obtained from the culture collection of the Regional center for mycology and biotechnology (RCMB), Al-Azhar University, Cairo, Egypt. Antimicrobial assays were carried out using an agar well diffusion method by using approved standard method (M38-A \& M44-P, respectively) developed by the National Committee for Clinical Laboratory Standards [29]. The agar plates were prepared and the homogenous inocula of bacteria and fungus (in log phase) was made, then spreaded by swabbing on the solidified agar media (nutrient agar for tested bacteria and malt extract agar for tested fungi), in Petri-dishes (150 mm x $20 \mathrm{~mm}$ ). Under aseptic condition, the plates were then punched with a $5 \mathrm{~mm}$ diameter cork-borer to create wells. The tested samples were suspended in DMSO at $10 \mathrm{mg} / \mathrm{mL}$, and $100 \mu \mathrm{l}$ of each suspended sample was added into each well. A well loaded with the solvent was used as negative control. The agar plates were incubated for $48 \mathrm{~h}$ at $28 \pm 2^{\circ} \mathrm{C}$ and $24 \mathrm{~h}$ at $37 \pm 2^{\circ} \mathrm{C}$ for fungi and bacteria, respectively. All experiments were carried out in triplicate. The antimicrobial activity of the tested substances was determined by measuring the sizes of inhibitory zones in millimeter (including the diameter of wells) on the agar surface around the wells. The results are reported as the mean of zones of inhibition \pm standard deviation calculated from the triplicate samples for each test.

\subsubsection{Assessment of Antitumor activity}


The prepared materials were tested against two tumor cell lines i.e., Cervical cancer cell line (HeLa) and Colon carcinoma cell line (HCT-116) using crystal violet viability assay [30]. All the experiments concerning the cytotoxicity evaluation were performed and analyzed by tissue culture unit at the Regional Center for Mycology and Biotechnology, Al-Azhar University, Cairo, Egypt. In brief, the tumor cell lines were seeded in 96 -well plate in $100 \mu$ of growth medium at a cell concentration of $1 \times 10^{4}$ cells per well. After $24 \mathrm{~h}$ of seeding, the cell monolayers were treated with different concentration from the tested compound. The microtiter plates were incubated at $37^{\circ} \mathrm{C}$ in a humidified incubator with $5 \% \mathrm{CO}_{2}$ for a period of $24 \mathrm{~h}$. Three independent experiments were performed each containing six replicates for each concentration of the tested samples. Vinblastine sulfate was used as positive control. Untreated cells were served as controls. Because the stock solutions to prepare the different concentrations from the tested compounds were solubilized in DMSO, controls with DMSO alone were performed in parallel for each concentration.

The cytotoxic effects of the tested compounds were then measured using crystal violet staining viability assay. Briefly, after $24-\mathrm{h}$ of treatment, the medium was removed, $100 \mu \mathrm{L}$ of $0.5 \%$ of crystal violet in $50 \%$ methanol was added to each well and incubated for 20 minutes at room temperature and subsequently excess dye was washed out gently by distilled water. The plate was allowed to dry then the viable crystal violet-stained cells were lysed using $33 \%$ glacial acetic acid solution. Absorbance at $570 \mathrm{~nm}$ was then measured in each well using microplate reader (SunRise, TECAN, Inc, USA). The percentage cell viability was calculated as follows: \% cell viability $=[1-(\mathrm{ODt} / \mathrm{ODc})] \times 100 \%$, where ODt is the mean optical density of wells treated with the tested compound and ODc is the mean optical density of untreated cells. The test compounds were also compared using the $\mathrm{IC}_{50}$ value, i.e., the concentration of an individual compound leading to $50 \%$ cell death that was estimated from graphical plots of surviving cells vs compound concentrations.

\section{RESULTS AND DISCUSSION}

Metal complex (4-VP-Ni) synthesized by the reaction of 4vinyl pyridine (ligand) with nickel salt in ethanol at $60{ }^{\circ} \mathrm{C}$ for one hour Figure (1). The obtained metal complex was dried under vacuum over $\mathrm{P}_{4} \mathrm{O}_{10}$. Polymerisable metal complex synthesized by reaction of VP-Ni complex with methyl methacrylate in presence of AIBN as initiator. Figure (2). Metal complex and polymer metal complex are stable at room temperature, insoluble in water and common solvent, viz: $\mathrm{MeOH}$, $\mathrm{EtOH}, \mathrm{CHCl}_{3}, \mathrm{CCl}_{4},\left(\mathrm{CH}_{3}\right)_{2} \mathrm{CO}$ and DMF but soluble in DMSO. The physicochemical data of the VP-Ni complex are given in Table (1), spectral data are compatible with the proposed structures.

4

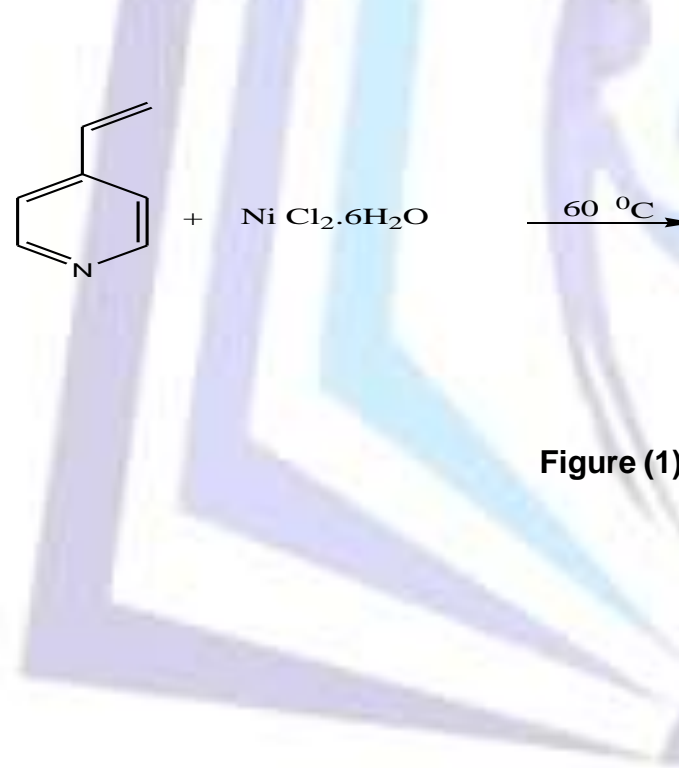



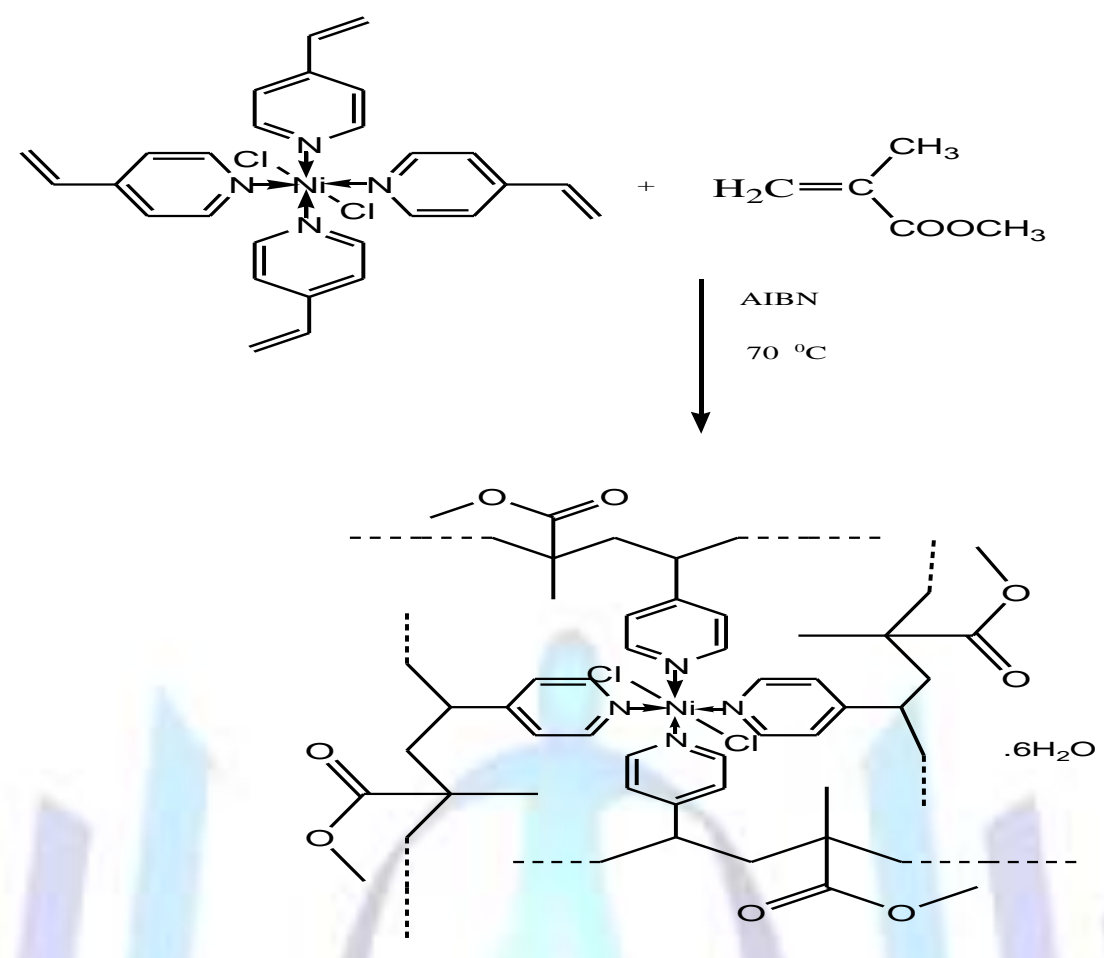

Figure (2) : Synthesis of polymer Ni complex.

\subsection{Conductivity}

The molar conductance value of VP-Ni complex in DMSO $\left(10^{-3} \mathrm{M}\right)$ is $11.6 \Omega \mathrm{mol}^{-1} \mathrm{~cm}^{2}$ (Table 1), reveals nonelectrolytic nature of the complex. This confirms that, the anion is coordinated to the metal ion.

\subsection{IR spectra}

The IR spectrumof the 4-VP-Ni and MMA-VP-Ni compounds are presented in figure 3 and 4, respectively. In the spectra of 4-vinyl pyridine, the peaks at 1599,1548 and $1496 \mathrm{~cm}^{-1}$ are attributed to $\mathrm{C}=\mathrm{N}$ stretching and ring vibration [32]. In the spectra of 4-VP-Ni these frequencies are shifted to 1625, 1492 and 1425 [33], clearly indicating that the ligand is bonded to the central metal atom through the hetero $\mathrm{N}$-atom. This is also confirmed by the appearance of new bands at 259 and $261 \mathrm{~cm}^{-1}$ this have been assigned to the M-N in 4-VP-Ni and MMA-VP-Ni, respectively [34]. In the spectra of the MMAVP-Ni the intensity of the beaks decrease. The bands of the $\mathrm{C}=\mathrm{N}$ stretching of the pyridine ring displaced to 1622,1490 and $1421 \mathrm{~cm}^{-1}$ [35]. The absorption band at $1710 \mathrm{~cm}^{-1}$ is assigned to the $\mathrm{C}=\mathrm{O}$ in MMA-VP-Ni and this band not found in 4-VP/Ni. The absorption band at $1125 \mathrm{~cm}^{-1}$ is assigned to the C-O in MMA-VP-Ni [36].The absorption band at $996 \mathrm{~cm}^{-}{ }^{1}$ is assigned to the $-\mathrm{C}-\mathrm{H}$ bending in 4-VP-Ni and $1019 \mathrm{~cm}^{-1}$ in MMA-VP-Ni [33]. We have found that the absorption band at $733 \mathrm{~cm}^{-1}$ is due to the stretching vibration of Ni-Cl bond in 4-VP-Ni and it shifted to $628 \mathrm{~cm}^{-1}$ due to polymerization in MMA-VP-Ni [37]

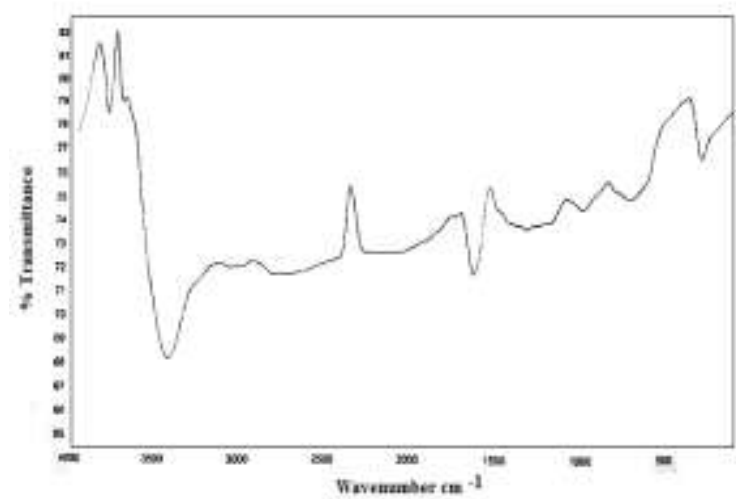

Figure 3 : IR spectrum of the (4-VP-Ni).

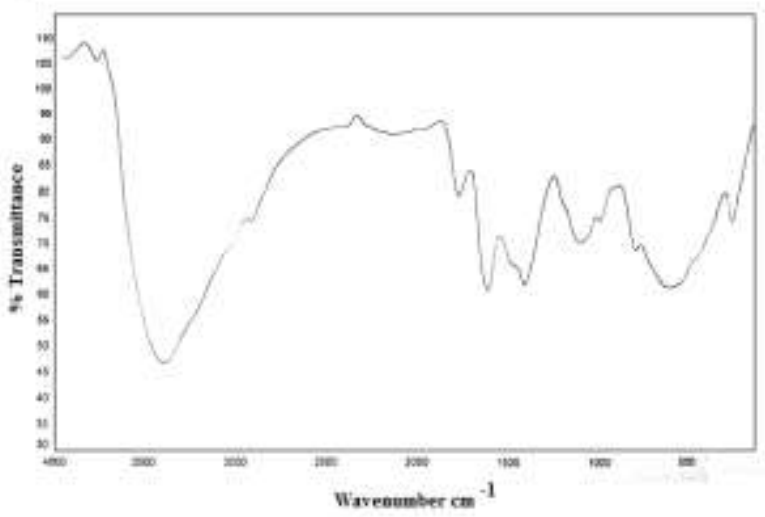

Figure 4 : IR spectrum of the (MMA-VP-Ni). 


\section{3. ${ }^{1} \mathrm{H}-\mathrm{NMR}$ spectra}

The ${ }^{1} \mathrm{H}-\mathrm{NMR}$ spectra of $4-\mathrm{VP}-\mathrm{Ni}$, show peak at $9.1 \mathrm{ppm}$ is assigned to proton of $\mathrm{CH}=\mathrm{N}$. The aromatic proton observed at $8.079 \mathrm{ppm}$ [37]. The peak at $5.162 \mathrm{ppm}$ is assigned to proton of $\mathrm{HC}=\mathrm{C}$ which attach to pyridine ring . The peaks at 5.10 and $5.088 \mathrm{ppm}$ are assigned to proton of $\mathrm{C}=\mathrm{CH}_{2}$. However, for MMA-VP-Ni, the peak at $8.5 \mathrm{ppm}$ is assigned to proton of $\mathrm{CH}=\mathrm{N}$. Aromatic proton observed at $7.4 \mathrm{ppm}$. The peak at $3.303 \mathrm{ppm}$ is assigned to proton of $\mathrm{C}-\mathrm{CH}-\mathrm{C}$ which attached to pyridine ring. The peaks at 2.532 and $2.528 \mathrm{ppm}$ are assigned to proton of $\mathrm{C}-\mathrm{CH}_{2}-\mathrm{C}-\mathrm{C}=\mathrm{O}$ and The peak at $2.498 \mathrm{ppm}$ isassigned to proton of $\mathrm{C}-\mathrm{CH}-\mathrm{C}=\mathrm{O}$. The peak at $1.733 \mathrm{ppm}$ is assigned to proton of $\mathrm{C}-\mathrm{CH}_{2}-\mathrm{C}$ [36].

\subsection{Mass spectra of 4-VP complex}

The mass spectra of $\mathrm{Ni}(\mathrm{II})$ complex 4-VP-Ni shows peak $(\mathrm{m} / \mathrm{z})$ at $658 \mathrm{amu}$, consistent with the molecular weight of the $\mathrm{Ni}$ (II) complex. Additionally, the peaks observed at 105,108, 130, 235, 340, 445, 550 and 553 are due to $\mathrm{C}_{7} \mathrm{H}_{7} \mathrm{~N}_{1} \mathrm{H}_{12} \mathrm{O}_{6}$, $\mathrm{NiCl}_{2}, \mathrm{C}_{7} \mathrm{H}_{7} \mathrm{Cl}_{2} \mathrm{NNi}, \mathrm{C}_{14} \mathrm{H}_{14} \mathrm{Cl}_{2} \mathrm{~N}_{2} \mathrm{Ni}, \mathrm{C}_{21} \mathrm{H}_{21} \mathrm{Cl}_{2} \mathrm{~N}_{3} \mathrm{Ni}$ and $\mathrm{C}_{28} \mathrm{H}_{28} \mathrm{Cl}_{2} \mathrm{~N}_{4} \mathrm{Ni}$ moieties, respectively. The spectral data of the $\mathrm{Ni}(\mathrm{II})$ Complex (4-VP-Ni) is presented in table 2.

Table 2 : Mass spectra of Ni (II) complex (4-VP-Ni).

\begin{tabular}{ccc}
\hline $\mathrm{m} / \mathrm{z}$ & Rel. Int. & Fragment \\
\hline 105 & 100 & $\mathrm{C}_{7} \mathrm{H}_{7} \mathrm{~N}$ \\
\hline 108 & 1.9 & $\mathrm{H}_{12} \mathrm{O}_{6}$ \\
\hline 130 & 1.5 & $\mathrm{NiCl}_{2}$ \\
\hline 235 & 3.7 & $\mathrm{C}_{7} \mathrm{H}_{7} \mathrm{Cl}_{2} \mathrm{NNi}$ \\
\hline 340 & 0.81 & $\mathrm{C}_{14} \mathrm{H}_{14} \mathrm{Cl}_{2} \mathrm{~N}_{2} \mathrm{Ni}$ \\
\hline 445 & 0.23 & $\mathrm{C}_{21} \mathrm{H}_{21} \mathrm{Cl}_{2} \mathrm{~N}_{3} \mathrm{Ni}$ \\
\hline 550 & 0.77 & $\mathrm{C}_{28} \mathrm{H}_{28} \mathrm{Cl}_{2} \mathrm{~N}_{4} \mathrm{Ni}$ \\
\hline 658 & 1.85 & $\mathrm{C}_{28} \mathrm{H}_{40} \mathrm{Cl}_{2} \mathrm{~N}_{4} \mathrm{NiO}_{6}$
\end{tabular}

\subsection{Thermal analysis}

The thermal curves in the temperature $27-1000^{\circ} \mathrm{C}$ range for metal complex and polymer complex are thermally stable up to $60^{\circ} \mathrm{C}$. Dehydration is characterized by endothermic peak within the temperature $65-75^{\circ} \mathrm{C}$ range. The decomposition step for 4-VP-Ni shows endothermic peak at $75.2^{\circ} \mathrm{C}$ is due to loss of six hydrated water molecules with $8.22 \%$ weight loss [38]. However, the endothermic peak observed at $279^{\circ} \mathrm{C}$ with $26.59 \%$ weight loss may be assigned to the loss of VP unit $[34,13]$. Oxidative thermal decomposition occurred at $359^{\circ} \mathrm{C}$ with exothermic peaks, leaving NiO. MMA-VP-Ni shows endothermic peak at $65.2^{\circ} \mathrm{C}$ with $5.75 \%$ weight loss, are assigned to elimination of six hydrated water molecules. The endothermic peak observed at $259^{\circ} \mathrm{C}$ with $24.88 \%$ weight loss may be assigned to the loss of VP unit [39]. Oxidative thermal decomposition occured at $350^{\circ} \mathrm{C}$ with exothermic peaks, leaving NiO. The thermal data are shown in table 3 and the thermograms of 4-VP-Ni and MMA-VP-Ni are shown in figures 5 and 6 , respectively.

Table 3 : Thermal data for 4-VP-Ni and MMA-VP-Ni compounds.

\begin{tabular}{|c|r|c|c|c|}
\hline Compound & $\begin{array}{c}\text { Temp. } \\
\left({ }^{\circ} \mathrm{C}\right)\end{array}$ & $\begin{array}{c}\text { DTA } \\
\text { (Peak) }\end{array}$ & $\begin{array}{c}\text { TGA(Wt.loss\%) } \\
\text { Found }\end{array}$ & Assignment \\
\hline & 75.2 & Endo & 8.22 & Loss of six hydrated water \\
& 279 & Endo & 26.59 & Loss of VP unit \\
& 359 & Exo & 4.98 & Thermal decomposition with the formation NiO \\
& 65.2 & Endo & 5.75 & Loss of six hydrated water \\
& 259 & Endo & 24.88 & Loss of VP unit \\
\hline MMA-VP-Ni & 350 & Exo & 5.77 & Thermal decomposition with the formation NiO \\
\hline
\end{tabular}




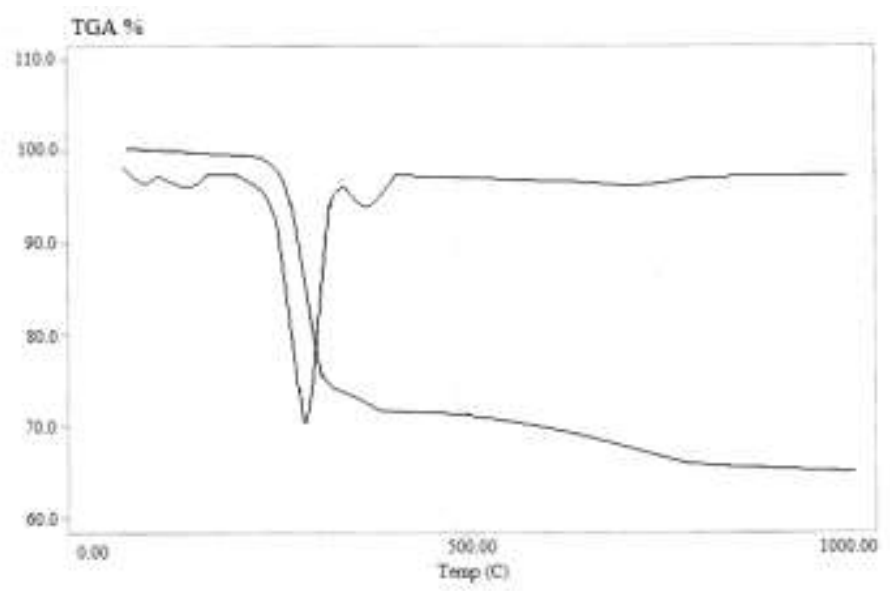

Figure 5 : Thermogram of (4-VP-Ni).

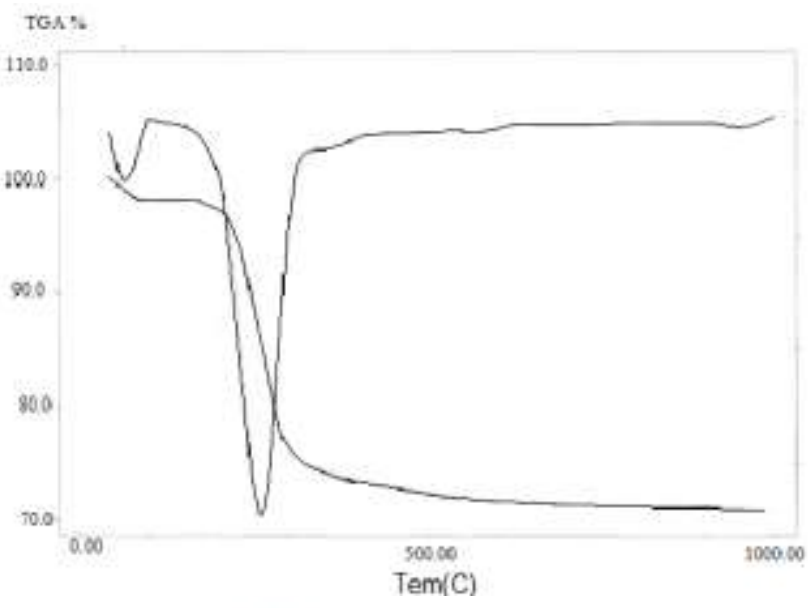

Figure 6 : Thermogram of the (MMA-VP-Ni).

\subsection{Antimicrobial activity}

The antimicrobial activity of the compounds was performed using a modified well diffusion agar technique on four pathogenic bacterial strains (Escherichia coli, Pseudomonas aeruginosa, Bacillus subtilis and Streptococcus pneumoniae) and two pathogenic fungal strains (Aspergillus fumigatus and Candida albicans). The results of the antimicrobial activities showed variations in activities among the tested compounds. Interestingly, some of the tested compounds also exhibited highest tendency to inhibit Gram positive bacteria than Gram negative bacteria. This activity can be explained on the basis of chelation theory [40]. All compounds were found with no antibacterial activity against the Psedomonas aeruginosa under the screening conditions. Additionally, none of the tested compounds exhibited antifungal activity against the Candida albicans under the screening conditions (Table 4 and 5). The antibacterial activity was observed by compound VP-Ni, followed by MMA-VP-Ni under the screening conditions. Moreover, the antifungal activities against Aspergillus fumigatus were observed for VP-Ni, followed by MMA-VP-Ni. The mode of action of the compounds may involve the formation of a coordinate bond groups with the active centers of the cell constituents resulting in an interference with the cell process (Table4 and 5).

Table 4: In vitro antibacterial activity of the compounds tested at $10 \mathrm{mg} / \mathrm{ml}$ by well diffusion agar assay and expressed as inhibition zone diameter $(\mathrm{mm})$ in the form of mean \pm SD.

\begin{tabular}{|l|c|c|c|c|}
\hline \multirow{2}{*}{$\begin{array}{l}\text { Tested } \\
\text { compounds }\end{array}$} & \multicolumn{2}{|c|}{ Gram-positive bacteria } & \multicolumn{2}{c|}{ Gram-negative bacteria } \\
\cline { 2 - 5 } & $\begin{array}{c}\text { Staphylococcus } \\
\text { pneumoniae }\end{array}$ & Bacillus subtilis & Escherichia coli & $\begin{array}{c}\text { Psedomonas } \\
\text { aeruginosa }\end{array}$ \\
\hline VP-Ni & $19.2 \pm 0.58$ & $20.3 \pm 0.53$ & $17.8 \pm 0.63$ & 0 \\
\hline MMA-VP-Ni & $16.2 \pm 2.0$ & $18.4 \pm 1.2$ & $15.3 \pm 2.0$ & 0 \\
\hline${ }^{*}$ Ampicillin & $23.8 \pm 0.2$ & $32.4 \pm 0.3$ & -- & $17.3 \pm 0.1$ \\
\hline *Gentamicin & -- & -- & $19.9 \pm 0.3$ & \\
\hline
\end{tabular}

* Ampicillin and Gentamicin were used as standard antibacterial drugs against Gram positive and Gram negative bacteria respectively.

Table 5: In vitro antifungal activity of the compounds tested at $10 \mathrm{mg} / \mathrm{ml}$ by well diffusion agar assay and expressed as inhibition zone diameter $(\mathrm{mm})$ in the form of mean $\pm \mathrm{SD}$

\begin{tabular}{|l|l|l|}
\hline \multirow{2}{*}{ Tested compounds } & \multicolumn{2}{|c|}{ Filamentous fungi } \\
\cline { 2 - 3 } & Aspergillus fumigatus & Candida albicans \\
\hline
\end{tabular}




\begin{tabular}{|c|c|c|}
\hline VP-Ni & $17.4 \pm 0.58$ & 0 \\
\hline MMA-VP-Ni & $12.3 \pm 1.5$ & 0 \\
\hline Amphotricin $\mathrm{B}^{*}$ & $23.7 \pm 0.1$ & $25.4 \pm 0.1$ \\
\hline
\end{tabular}

${ }^{*}$ Amphotricin B was used as standard antifungal drug

\subsection{Evaluation of the antitumor activities}

The antitumor activity of the compounds was performed using viability assay on two carcinoma cells (i.e. cervical cancer cell line (HeLa cells) and human colon carcinoma cell line (HCT-116 cells). The in vitro growth inhibitory rates (\%) and inhibitory growth activity (as measured by $\mathrm{IC}_{50}$ ) of the synthesized compounds were investigated in comparison with the well-known anticancer standard drug Imatinib (2-substituted aminopyrimidine derivative; Gleevec®). Data generated were used to plot dose response curves and presented in Fig. (7 \& 8). However, the results revealed that the tested compounds showed high variation in the inhibitory growth rates and activities against the tested tumor cell lines in a concentration dependent manner (Fig. 7\& 8). The difference between inhibitory activities of all compounds with different concentrations was statistically significant $P<0.001$. Furthermore, the highest activity against HCT-116 cells was detected for compound VP-Ni (with $\mathrm{IC}_{50}$ value $9.8 \pm 0.6 \mu \mathrm{g} / \mathrm{ml}$ ), compared with reference standard $(24.6 \pm 0.3 \mu \mathrm{g} / \mathrm{ml}$ ) followed by MMA-VP-Ni (48.3 \pm 1.5$)$ (Fig. 7). Lower sensitivity was detected for HeLa cell line (Fig. 8) showing higher $\mathrm{IC}_{50}$ values in the same trend of activity measured for HCT-116. This can be explained as Metal binds to DNA. It seems that, change the anion and the nature of the metal ion has effect on the biological behavior, due to alter binding ability of the DNA binding. Antitumor effect of the compounds may be attributed to the central metal atom which was explained by Tweedy's chelation theory [41]. Also, the positive charge of the metal increases the acidity of coordinated ligand that bears protons, leading to stronger hydrogen bonds which enhance the biological activity. Also, metal could act as a double-edged, sword by inducing DNA damage and also by inhibiting their repair. The $\mathrm{OH}$ radical reacts with DNA sugars and bases and the most significant and well-characterized of the $\mathrm{OH}$ reactions is hydrogen atom abstraction from the $\mathrm{C}_{4}$ on the deoxyribo unit to yield sugar radicals with subsequent $\beta$-elimination. Figure 9 , by this mechanism strand breakage occurs as well as the release of the free bases. Another form of attack on the DNA bases is by solvated electrons, probably via a similar reaction to those discussed below for the direct effects of radiation on DNA [41].

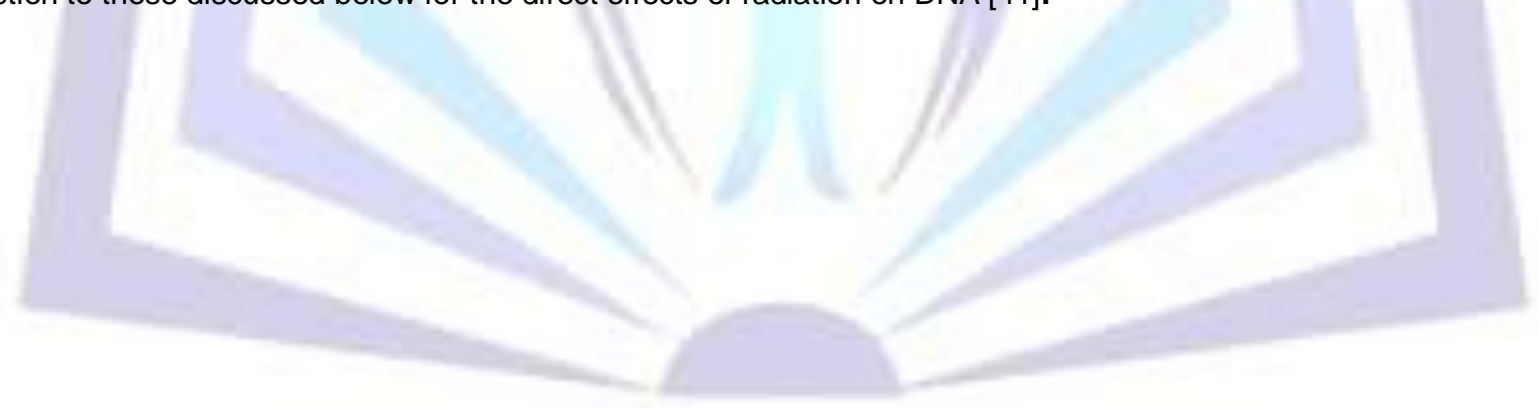




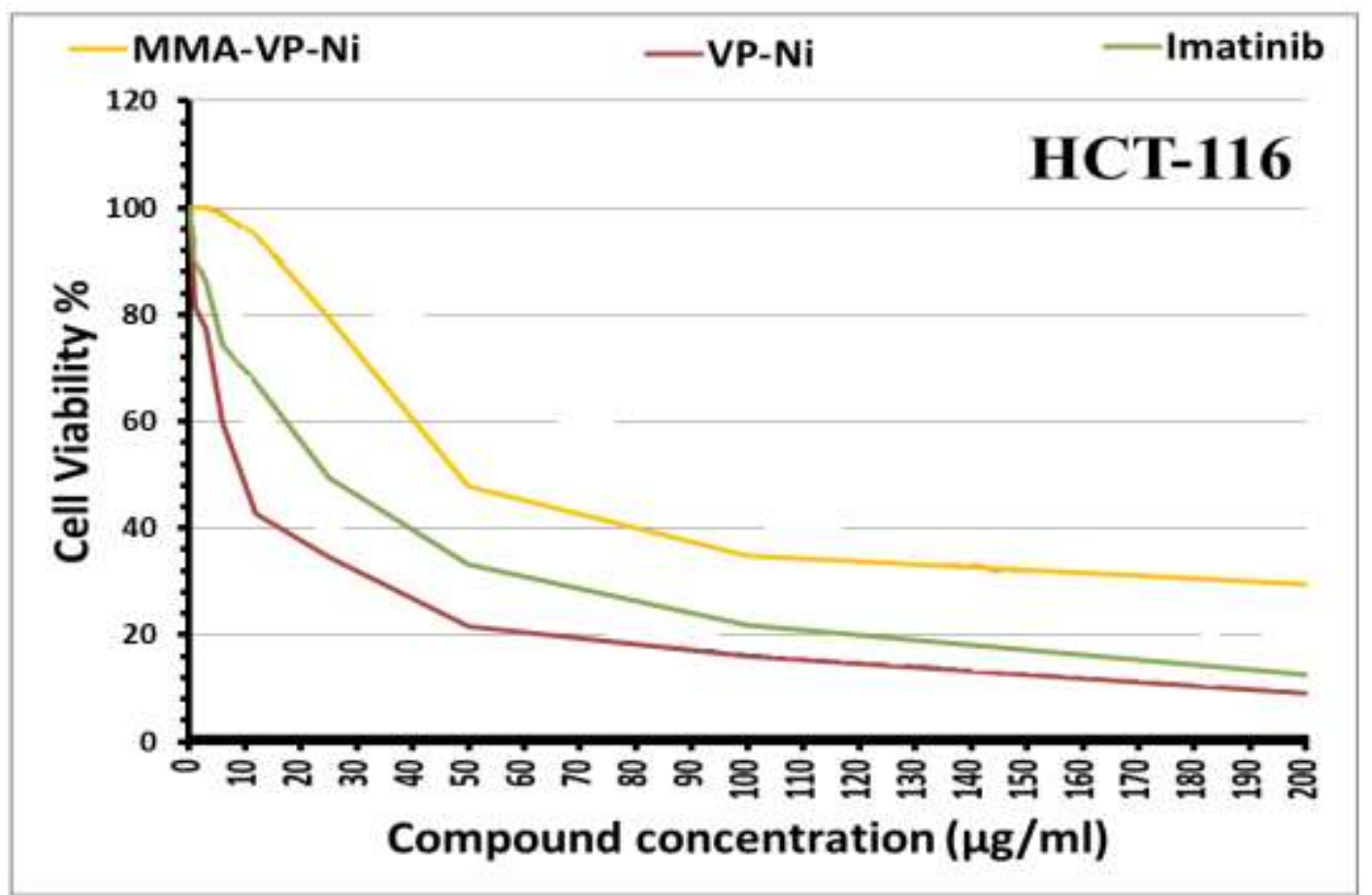

Figure (7): The dose response curve showing the in vitro inhibitory activity against human colon carcinoma (HCT-116) cell line showing the activity of the tested compounds and imitanib standard reference standard.

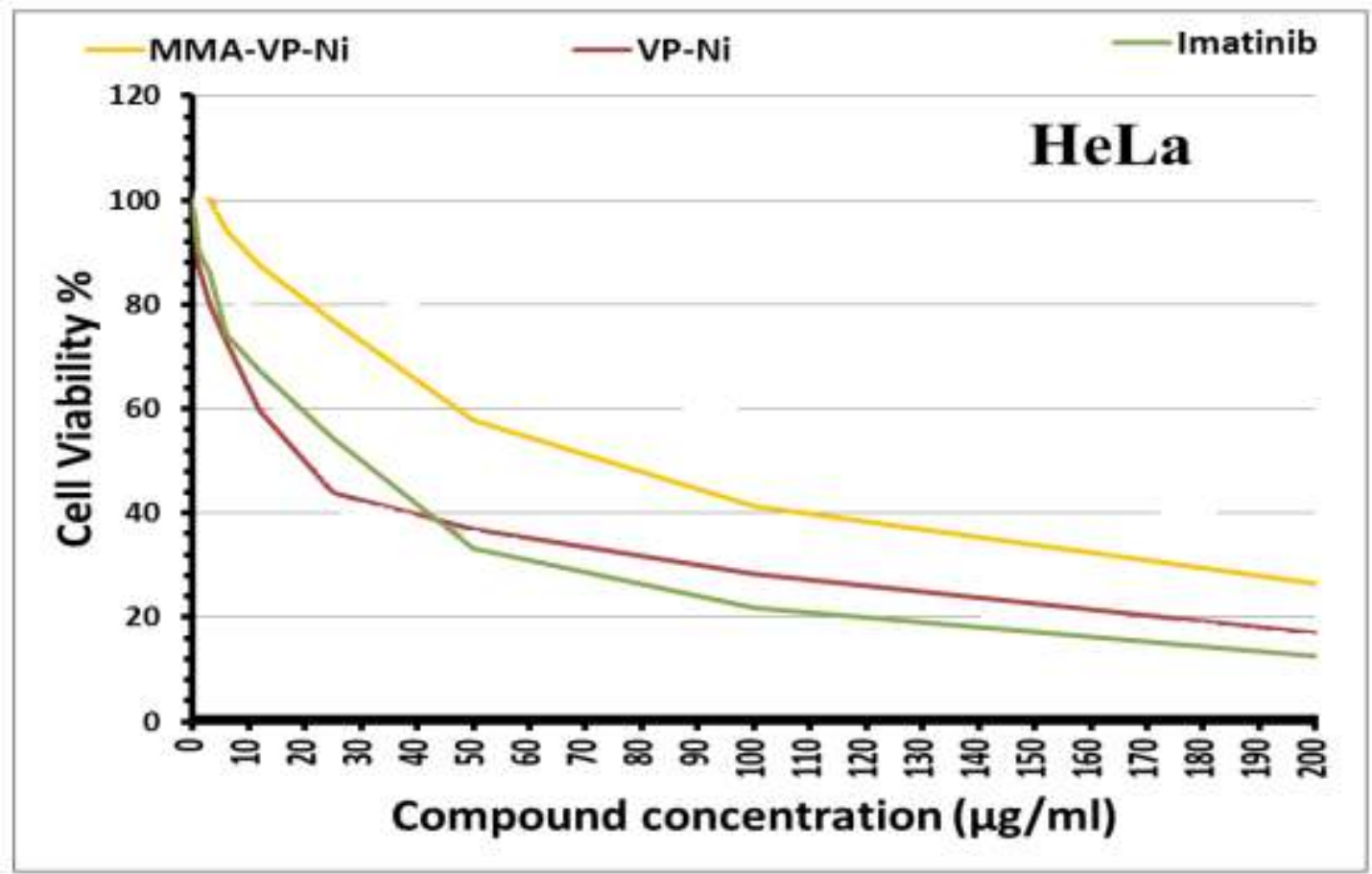

Figure (8): The dose response curve showing the in vitro inhibitory activity against human cervical carcinoma (HeLa) cell line showing the activity of the tested compounds and imitanib standard.

Table 6: The antitumor activities of the tested compounds compared with reference standard drug evaluated on colon and cervical cancer cell lines 


\begin{tabular}{|l|c|c|}
\hline \multirow{2}{*}{$\begin{array}{c}\text { Tested } \\
\text { compounds }\end{array}$} & \multicolumn{2}{|c|}{$\begin{array}{c}\mathrm{IC}_{50} \text { values }(\mu \mathrm{g} / \mathrm{ml}) \\
\text { against tumor cell lines }\end{array}$} \\
\cline { 2 - 3 } & HCT-116 & HeLa \\
\hline VP-Ni & $9.8 \pm 0.6$ & $20.1 \pm 1.5$ \\
\hline MMA-VP-Ni & $48.3 \pm 1.5$ & $73.4 \pm 0.8$ \\
\hline Imitanib & $24.6 \pm 0.3$ & $30.1 \pm 0.7$ \\
\hline
\end{tabular}<smiles>COP(=O)([O-])OC1CC([13CH3])OC1OP(=O)([O-])OC</smiles><smiles>COP(=O)([O-])OC1CC([18O])OC1OP(=O)([O-])OC</smiles>

\section{CONCLUSION}

$\mathrm{Ni}$ (II) Complex and polymer Ni complex have been prepared and characterized by elemental and spectral analyses. The IR data suggest the nitrogen of 4-VP in coordination to the central metal ion. The molar conductance of complex is commensurate with their non-ionic character. The compounds show cytotoxic effect against HELA and HCT-116 cell lines and also have effect against microbial organisms studied.

\section{REFERENCES}

[1] Camacho, D. H. and Guan, Z. B. Designing late-transition metal catalysts for olefin insertion polymerization and copolymerization. Chem. Commun. 46 (2010), 7879-7893.

[2] Lena, F. D. and Matyjaszewski, K. Transition metal catalysts for controllable radical polymerization. Prog. Polym. Sci. 35 (2010), 959-1021.

[3] Hao, J. J., Song, H. B. and Cui, C. M. Monomeric and linear polymer samarium (II)complexes of the 2-(N-arylimino) pyrrolide ligand. Organometallics. 28 (2009), 3100-3104.

[4] He, X. H., Yao, Y. Z., Luo, X., Zhang, J. K., Liu, Y. and Zhang, L. Nickel(II) complexes bearing N,O-chelate ligands: synthesis, solid-structure characterization, and reactivity toward the polymerization of polar monomer. Organometallics. 22 (2003), 4952-4957.

[5] He, X. H. and Wu, Q. Polymerization of methyl methacrylate using bis ( $\beta$-ketoamino)nickel(II)-MAO catalytic systems. Appl Organometal Chem. 20 (2006), 264-271.

[6] Carlini, C., Martinelli, M., Galletti, A. M. R. and Sbrana, G. Highly active methyl methacrylate polymerization catalysts obtained from bis (3,5-dinitro-salicylaldiminate) nickel(II) complexes and methyl aluminoxane. J Polym Sci A: Polym Chem. 41 (2003), 2117-2124.

[7] Tang, G. R. and Jin, G. X. Polymerization of methyl methacrylate catalyzed by nickel complexes with hydroxyindanone-imine ligands. Dalton Trans. (2007), 3840-3846.

[8] Carlini, C., Martinelli, M., Passaglia, E., Galletti, A. M. R. and Sbrana, G. Homopolymerization of methyl methacrylate by novel Ziegler-Natta-type catalysts based on bis(chelate)-nickel(II) complexes and methylaluminoxane. Macromol Rapid Commun. 22 (2001), 664-668.

[9] Carlini, C., Martinelli, M., Galletti, A. M. R. and Sbrana, G. Homopolymerization of methyl methacrylate by novel salicylaldiminate-nickel/methylaluminoxane catalysts obtained by oxidative addition of the chelate ligand to a nickel $(0)$ precursor. J Polym Sci A: Polym Chem. 41 (2003), 1716-1724.

[10] Carlini, C., Luise, V. D., Martinelli, M., Galletti, A. M. R. and Sbrana, G. Homo- and copolymerization of methyl methacrylate with ethylene by novel Ziegler-Natta-type nickel catalysts based on N,O-nitro-substituted chelate ligands. J Polym Sci A: Polym Chem . 44 (2006), 620-633.

[11] Fenger, I. and Le Drian, C. Reusable polymer-supported palladium catalysts: An alternative to 


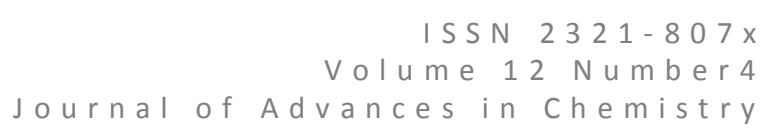

tetrakis(triphenylphine) palladium in the suzuki cross-coupling reaction. Tetrahedron Lett. 39 (1998), 4287-4290.

[12] Mizuta, T., Onishi, M. and Miyoshi, K. Photolytic ring-opening polymerization of phosphorous-bridged

Ferrocenophane coordinating to an organometallic fragment. Organometallics. 19 (24) (2000), 5005-5009.

[13] Kaliyappan, T., Swaminathan, C. S. and Kannan, P. Synthesis and characterization of a new metal chelating polymer and derived $\mathrm{Ni}(\mathrm{II})$ and $\mathrm{Cu}(\mathrm{II})$ polymer complexes. Polymer. 37 (1996), 2865-2869.

[14] Orazzhanova, L. K., Yashkarova, H. G., Issue, L. A. and Kudaibergenov, S. E. Binary and ternary polymer- strontium complexes and the capture of radioactive strontium-90 from the polluted soil of the semipalalinsk nuclear test site. J. Appl. Polym. Sci. 87 (5) (2003), 759-764.

[15] Varvara, S., Muresane, L., Popescu, I. C. and Maurin, G. Copper electrodeposition from sulfate electrolytes in the presence of hydroxyethylated-2-butyne-1, 4-diol. Hydrometallurgy. 75 (2004), 147-156.

[16] Ro, K. W., Chang, W. J., Kim, H., Koo, Y. M. and Hahn, J. H. Capilary electrochromatography and preconcentration of neutral compounds on poly(dimethylsiloxane) microchips. Electrophoresis. 24 (18) (2003), 3253-3259.

[17] Varghese, S., Lele, A. K., Sirnivas, D. and Mashellear, R. A. Role of hydrophobicity on structure of polymer- metal complexes. J. Phys. Chem. B. 105 (23) (2001), 5368-5373.

[18] Ahmed, M., Malik, M. A., Pervez, S. and Raffiq, M. Effect of porosity on sulfonation of macroporous styrenedivinylbenzene beads. Eur. Polym. J. 40 (2004), 1609-1613.

[19] James, S. L. Metal-organic frameworks. Chem. Soc. Rev. 32 (2003), 276-288.

[20] Maspoch, D., Ruiz-Molina, D. and Veciana, J. Magnetic nanoporous coordination polymers. J.Mater. Chem. 14 (2004), 2713-2723.

[21] Batten, S. R. and Murray, K. S. Structure and magnetism of coordination polymers containing dicyanamide and tricyanomethanide. Coord. Chem. Rev. 246 (1-2) (2003), 103-130.

[22] Janiak, C. Engineering coordination polymers towards applications. Dalton Trans. (2003), 2781-2804.

[23] Castro, I. U., Stuber, F., Fabregat, A., Font, J., Fortuny, A. and Bengoa, C. Supported Cu(II) polymer catalysts for aqueous phenol oxidation. J. Hazardous Materials. 163 (2009), 809-815.

[24] Turmanova, S., Vassilev, K. and Boneva, S. Preparation, structure and properties of metal-copolymer complexes of poly-4-vinylpyridine radiation-grafted onto polymer films. Reactive and Functional Polymers. 68 (2008), 759-767.

[25] Liqin, C., Chuang, M., Jide, W. and Pei, C. Synthesis of polymer-copper(II) complexes in supercritical carbon dioxide. The Journal of Supercritical Fluids. 75 (2013), 152- 158.

[26] Nagel, J. and Oertel, U. Langmuir-Blodgett layers from polymer-metal complexes: behaviour of monolayers and preparation of multilayers. Polymer. 36 (1995), 381-386.

[27] Kamrupi, I. R. and Dolui, S. K. Synthesis of copper-polystyrene nanocomposite particles using water in supercritical carbon dioxide medium and its antimicrobial activity. J. Applied Polymer Science. 120 (2011), 1027-1033.

[28] Kamrupi, I. R., Phukon, P., Konwer, B. K. and Dolui, S. K. Synthesis of silver-polystyrene nanocomposite particles using water in supercritical carbon dioxide medium and its antimicrobial activity. J. Supercritical Fluids. 55 (2011), 10891094.

[29] National Committee for Clinical Laboratory Standards, Reference Method for Broth Dilution Antifungal Susceptibility Testing of Conidium Forming Filamentous Fungi; Proposed Standard, NCCLS Document M38-A; Wayne, PA, USA,

(2002).

[30] Wilson AP In: Masters JRW (ed) Cytotoxicity and viability assays in animal cell culture: A Practical Approach, $3^{\text {rd }}$ edn. Oxford University Press, Oxford (2000).

[31] Elaasser, M. M., Abdel-Aziz, M. M. and El-Kassas, R. A. Antioxidant, antimicrobial, antiviral and antitumor activities of pyranone derivative obtained from Aspergillus candidus. J. Microbiol Biotech Res. 1(2011), 5-17.

[32] Srivastava, T. N., Tandon, S. K. and Bhakru, N. O. Complexes of zirconium and thorium perchlorates with some heterocyclic bases. Inorg. Nucl. Chem. 40(1978), 1180-1181.

[33] Bayarl, S., Ide, S. and Yurdakul, S. Spectroscopic and structural studies on metal halide complexes of 4vinylpyridine. Journal of Molecular Structure. 560 (2001), 95-103.

[34] Agarwal, R. K., Kishor, A., Himanshu, A. and Sarin , R. K. Synthesis and structural investigations of thorium (IV) and dioxouranium (VI) complexes of 4-vinyl pyridine. Synth. React. Inorg. Met-Org. Chem. 25(6) (1995), 899-913.

[35] Drelinkiewicza, A., Hasikb, M., Quillardc, S. and Paluszkiewicz, C. Infrared and Raman studies of palladiumnitrogen-containing polymers interactions. J. Molecular Structure. 511 (1999), 205-215.

[36] Nurulsaidah, A. R., Fabrice, A., Brendan, T., Johannes, G. V. and Andreas, H. Synthesis of poly(4-vinyl pyridine-bmethyl methacrylate) by MAMA-SG1 initiated sequential polymerization and formation of metal loaded block copolymer inverse micelles. European Polymer Journal. 48 (2012), 990 - 996.

[37] Faridul, I., Amran, H., Nur, M. S., Hridika, T. B., Alamgir, K., Mohamed, J. K. and Romel, M. Syntesis,

Characterization, and Antimicrobial activity studies of Ni(II) Complex with Pyridine as a Ligand. Journal of Chemistry. 2015 (2015), 1-8.

[38] Alvaro, J., Alcides, D., Jorge, E., Ya'nez. and Paulino, B. Spectroscopic characterization of coordination complexes based on dichlorocopper(II) and poly(4-vinylpyridine): Application in catalysis. Polyhedron. 24 (2005), 511-519.

[39] Hafida, H. F., Kamel, O., and Said, D. Synthesis, characterization and thermal behavior of poly (methyl methacrylate), copolymers of methylmethacrylate with 4-vinyl pyridine and maghnia bentonite nanocomposites initiated by Ni (II)benzoinoxim complex. Polymer Preprints. 50 (2) (2009), 250-251.

[40] El -Tabl , A. S., El-Said, F. A. and Al-Hakimi, A. N. Synthesis, spectroscopic investigation and biological activity of metal complexes with ONO trifunctionalalized hydrazone ligand. Transition Metal Chemistry. 32 (2007), 689-701.

[41] El-Tabl, A. S., Abd El-Waed, M. M. and Rezk, A. M. S. M. Cytotoxic behavior and spectroscopic characterization of metal complexes of ethylacetoacetate bis(thiosemicarbazone)ligand. Spectrochimica acta part A: Molecular and Biomolecular Spectroscopy.117 (2014), 772-788. 